\title{
Quality Characteristics of Fortified Bread Produced from Cassava and Mushroom Flours
}

Azeez LA*, Adedokun SO, Adeoti AO and Babalola JO

Department of Food Science and Technology, The Oke-Ogun Polytechnic Saki, Oyo State, Nigeria

\begin{abstract}
Cassava substitution with wheat has been generally encouraged in the tropic economy but deficiency in protein of Cassava has made the needs for supplementing with high protein product. Thus, the effects of addition of mushroom to cassava to produced bread were investigated. Samples of the blends used in the study are 95:5, 90:10. 85:15, 80:20 and 75:25\% cassavamushroom respectively while $100 \%$ wheat flour was used as control. The breads produced were evaluated for their proximate, minerals, functional and sensory properties. Results showed that the proximate composition of bread from the composite flour ranged from $10.11 \%$ to $11.34 \%$ for moisture, $8.84 \%$ to $10.03 \%$ protein, $3.06 \%$ to $3.75 \%$ fat, $2.03 \%$ to $2.56 \%$ ash, $2.23 \%$ to $2.73 \%$ fiber, and $70.03 \%$ to $74.55 \%$ carbohydrate. The mineral contents: Fe, Ca, K, P of the produced bread increased with increased in the incorporation level of mushroom flour. The functional properties varied from $93.42 \%$ to $101.23 \%, 0.61 \%$ to $0.74 \%, 10.88 \%$ to $15.35 \%, 9.34 \%$ to $10.32 \%$ and $2.14 \%$ to $3.74 \%$ for the water absorption capacity, bulk density, swelling power, oil absorption capacity and solubility respectively. There was no significant difference $(p>0.05)$ in flavor and overall acceptability of the bread while significant differences ( $p>0.05)$ existed in texture, taste and appearance. Sensory evaluation of the cassava-mushroom bread indicated that the bread sample containing 75:25\% CF/MP was the most acceptable. This result suggests that cassava flour could serve as a good substitute for wheat flour in the production of bread and addition of mushroom could improve its nutritional quality.
\end{abstract}

Keywords: Fortified bread; Cassava; Mushroom; Chemical and sensory properties

\section{Introduction}

Bread is a staple foodstuff and is eaten in most countries around the world. It is a fermented confectionary product produced mainly from wheat flour, water, yeast and salt by a series of process involving mixing, kneading, proofing, shaping and baking [1]. In Nigeria, the consumption of ready-to-eat baked products is continually growing and there has been an increase in reliance on imported wheat [2]. Moreover, Nigeria grows staple crops other than wheat such as cassava, sweet potato, yam and cereals that can be used for bakery foods. It would therefore be of economic advantage if wheat flour could be replaced with local indigenous crops other than wheat such as cassava and mushroom in the production of bread. Hence reducing the reliance on its importation and thus enhance the industrial utilization of local crops.

Cassava (Manihot esculenta crantz) is a perennial woody shrub with an edible root, which grows in tropical and sub-tropical areas of the world and is one of the leading food and feed plants in the world: it ranks fourth among staple crops with a global production of about 160 million tons per year [3]. Cassava also grows at a suboptimal condition; it is tolerant of soil infertility and drought stress and can be stored underground for several months after maturation [4,5]. Nigeria has been consistently ranked as the world largest producer of cassava with an annual output of over 34 million tons of tuberous root and it plays a dominant role in the rural economy in the southern agro-ecological zone [6]. Research carried out at the International Institute of Tropical agriculture (IITA) Ibadan, have shown that it is possible to use $10 \%$ cassava for baking. Therefore, research has been made in the use of composite flour through the incorporation of protein-rich non-wheat flour such as edible mushroom which has better nutritional qualities than wheat [7].

Mushrooms are edible fungi that contain high quality digestible protein that varied between ( $10 \%$ to $40 \%$ ), carbohydrate (3\% to $21 \%$ ) and dietary fiber (3\% to $35 \%$ ) on dry weight basis depending on species [8]. Most species contain all the essential amino acids about the same proportion as in egg $[9,10]$. It is also a good source of B-vitamins (thiamin, riboflavin, niacin, biotin, pyridoxine, pantothenic acid) and vitamin C. It also contains significant number of mineral elements like phosphorus, iron, potassium and calcium [9]. Their content of carbohydrate and fat make them ideal for diabetic patient and person who wish to shed excess fat [11]. The aim of this research is to produce acceptable and nutritionally balanced high-quality bread from the whole replacement of wheat flours with locally grown crops (cassava and mushroom) blends.

\section{Materials and Methods}

\section{Sources of materials}

Fresh cassava roots (Manihot esculenta) were procured from Tewu farm in Saki area, Oyo State. Fresh edible mushroom (Pleurotus ostreatus) was obtained from Adeshola Farms Ogbomosho, Oyo State. Blue band margarine, baker's brand of yeast, table salt and other ingredients were obtained from Sango Market in Saki, Oyo State, while baking equipment's and other instrument was provided by the Department of Food Science and Technology, The Oke-Ogun Polytechnic, Saki.

\section{Processing methods}

Preparation of mushroom powder: The fresh edible Pleurotus ostreatus was processed into mushroom powder by using the method

${ }^{*}$ Corresponding author: Azeez LA, Department of Food Science and Technology, The Oke-Ogun Polytechnic Saki, Oyo State, Nigeria, Tel: 08153921979; E-mail lukmak2011@yahoo.com

Received February 22, 2018; Accepted March 13, 2018; Published March 20, 2018

Citation: Azeez LA, Adedokun SO, Adeoti AO, Babalola JO (2018) Quality Characteristics of Fortified Bread Produced from Cassava and Mushroom Flours. Food Process Technol 9: 724. doi: 10.4172/2157-7110.1000724

Copyright: @ 2018 Azeez LA, et al. This is an open-access article distributed under the terms of the Creative Commons Attribution License, which permits unrestricted use, distribution, and reproduction in any medium, provided the original author and source are credited. 
described by Okeke et al. [12]. The fresh mushroom was cleaned and washed properly to remove dirty and their field damaged portion. The fresh mushroom was blanched in hot water at $32^{\circ} \mathrm{C}$ for three minutes, which contained $3 \%$ salt and $0.01 \%$ citric acid. Then water was drained, and the mushroom was dried in an oven which was maintained at $105^{\circ} \mathrm{C}$ for 3 hours. The dried mushroom was milled in the laboratory using hammer mill and was passed through a 60-inch mesh sieve (British Standard Screen) and packaged in a low-density polyethylene bag, stored in the refrigerator $\left(4^{\circ} \mathrm{C}\right)$ for further use as shown in Figure 1.

Preparation of cassava flour: Cassava flour was prepared from freshly harvested cassava roots. The roots were sorted, washed with clean water to remove soils and another foreign particle. It was peeled with a knife and re-washed. The peeled roots were then cut into chips and soaked in $0.1 \%$ sodium metabisulphite for $10-20$ minutes to prevent browning. The chips were drained, and oven dried at $105^{\circ} \mathrm{C}$ for $3 \mathrm{hrs}$. Dried chips was cooled at room temperature $\left(30^{\circ} \mathrm{C} \pm 2^{\circ} \mathrm{C}\right)$ and was milled by attrition mill into fine powder and sieved through 60 mesh screen, packaged in polyethylene bag and stored in for subsequent used as shown in Figure 2.

Baking process of cassava-mushhroom bread: Four different formulations of cassava-mushroom blend used were: 95:5, 90:10. 85:15, $80: 20,75: 25 \%$ of cassava and mushroom, respectively. Bread from

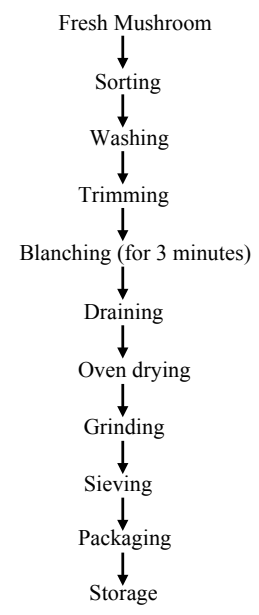

Figure 1: Flow chart for the preparation of mushroom powder [16]

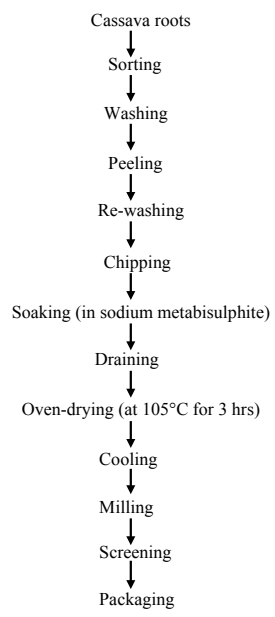

Figure 2: Flow chart for the prerparation of cassava flour.

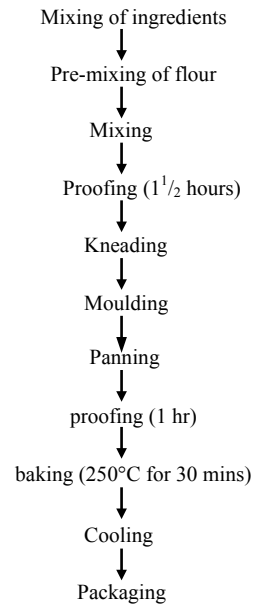

Figure 3: Flow chart for the production of bread [13]

$100 \%$ wheat flour was also produced to serves as control. Production of bread was carried out on the blends by using standard bread baking procedure established for the straight dough method [13] as shown in the Figure 3. While the details of ingredients used in the formulation were expressed as the percentage of the flour used: water $43.6 \%$; sugar, $8.3 \%$; salt, $0.9 \%$; milk, $2.3 \%$; dried yeast, $0.4 \%$; margarine, $16.6 \%$; vanilla flavor 0.25 .

\section{Determination of proximate analysis}

The moisture, protein, fat, ash, and crude fiber contents were determined following the procedure outline by AOAC [14], while carbohydrate was calculated by difference.

Carbohydrate $=100-(\%$ moisture $+\%$ protein $+\%$ fat $+\%$ ash + $\%$ crude fiber) [15].

\section{Determination of mineral analysis}

Iron, calcium, potassium and phosphorus were determined by AOAC [14] method using Atomic Absorption Spectrophotometer (AAS) (Perkin-Elmer-Crop, Norwalk, model 560).

\section{Determination of functional properties}

Determination of bulk density: The procedure of Okaka and Porter [16] was employed to determine the bulk density of the samples. $50 \mathrm{~g}$ flour sample was put into a $100 \mathrm{ml}$ measuring cylinder. The cylinder was tapped several times on a laboratory bench to a constant volume. The volume of sample was recorded. The cylinder was severally tapped against a table until there was no further change in volume. tapping.

Bulk density $\left(\mathrm{g} / \mathrm{cm}^{3}\right)=$ Weight of sample/Volume of sample after

Determination of water absorption capacity: The procedure of Sather et al. [17] was used. $20 \mathrm{ml}$ of distilled water was added to $1.0 \mathrm{~g}$ of samples and blended at high speed for 30 seconds. The mixture was allowed to stand at $30^{\circ} \mathrm{C}$ for 30 minutes. The supernatant obtained was measured using a $10 \mathrm{ml}$ graduated cylinder. The density of the water was determined in $\mathrm{g} / \mathrm{ml}$.

Determination of swelling capacity and solubility index: The method described by Takashi and Sieb [18] was used with slight modifications. It involved weighing $1 \mathrm{~g}$ of flour blend sample into $50 \mathrm{ml}$ centrifuge tube. Fifty $\mathrm{ml}$ of distilled water was added and mixed 
gently. The slurry was heated in a water bath at $70^{\circ} \mathrm{C}, 80^{\circ} \mathrm{C}, 90^{\circ} \mathrm{C}$ and $100^{\circ} \mathrm{C}$ respectively for $15 \mathrm{~min}$. During heating, the slurry was stirred gently to prevent clumping of the flour. On completion of $15 \mathrm{~min}$, the tube containing the paste was centrifuged at $3000 \mathrm{rpm}$ for $10 \mathrm{~min}$ using centrifuge. The supernatant was decanted immediately after centrifuging. The weight of the sediment was taken and recorded. The moisture content of the sediments gel was therefore determined to get the dry matter content in the gel.

Swelling power $=\frac{\text { Weight of wet mass sediment }}{\text { Weight of dry matter in the gel }} \times 100$

Solubility index $(\%)=$ Weight of dry solid after drying $\times 100$

\section{Sensory evaluation}

The bread samples were subjected to organoleptic analysis within 24 hours of baking. The samples were evaluated by using a 20-man trained panelist on a 9-point hedonic scale of 9 (like extremely) to 1 (dislike extremely) for appearance, texture, taste, crumb and overall acceptability [19].

\section{Statistical analysis}

Data were analyses using analysis of variance and the significance of the observed differences between means was separated with Duncan Multiple Range Test procedures using SPSS version 19.0.

\section{Results and Discussion}

\section{Proximate composition of bread samples}

The proximate composition of cassava-mushroom bread samples and the control are shown in Table 1 . The moisture content of the breads samples ranged from $10.11 \%$ to $11.34 \%$. The highest percentage of moisture content was found in sample $95: 5 \%$ bread, while the control samples having the lowest value. The differences in moisture content with breads having different level of mushroom are very little and these findings are similar with the result of Mahedy et al. [20]. The difference between them is mostly due to different baking conditions, environmental issues and moisture absorbability of the ingredient in different conditions.

As shown in Table 1, the crude protein content of the samples varied from $8.85 \%$ to $10.03 \%$, bread sample $75: 25 \%$ of $\mathrm{CF} / \mathrm{MP}$, respectively having the highest value, while the least value was recorded for the control (100\%) wheat flour. Increase in the incorporation levels of mushroom powder to the flour blends resulted in increase in protein content of the blends. This result agrees with those reported by Mahedy et al. [20]. There was no significant difference between the crude fat, ash and fiber of the samples. The values obtained for the crude fat, ash and fiber of the samples increased progressively with the increased in the level of CF/MP.

The carbohydrate content of the bread samples was significantly increased as the amount of mushroom is reduced. The carbohydrate content increased from $70.03 \%$ to $71.66 \%$ with the highest value obtained from bread sample $95: 5 \%$. The result obtained is similar to those reported by Okafor et al. [21].

\section{Mineral content of cassava-mushroom bread}

The minerals content results for bread produced from cassavamushroom flour are shown in Table 2. The minerals contents of iron, calcium, potassium and phosphorus were gradually increased with increasing the incorporation level of $\mathrm{CF} / \mathrm{MF}$ mixture when compared with control bread. The higher mineral composition obtained in the bread produced compared to the control ( $100 \%$ wheat flour) was due to the high contents of mineral salt found in mushroom [22,23].

\section{Functional properties of cassava-mushroom bread}

The Functional properties of cassava-mushroom bread are shown in Table 3. The water absorption capacities affect the quality of baked goods and depend partly on the damaged starch contained in the flour, the protein content and particle size [24]. As shown from the Table 3, the water absorption capacity of the bread produced varied from $93.42 \%$ to $101.23 \%$. Bread sample $85: 15 \%$ of CF/MP, respectively having the highest value, while the control having the lowest value. The Swelling power or capacity increased from $10.85 \%$ to $11.13 \%$ with bread samples $95: 5 \%$ having the lowest value. The swelling power has been related to the association binding within the starch granules and apparently the strength and character of the micelle network as related to the amylase content of the flour. Low amylose content produces high swelling power [25]. There were no significant different in bulk density between the bread samples produced from $85: 15 \%$ and $80: 20 \%$ of $\mathrm{CF} /$

\begin{tabular}{|c|c|c|c|c|c|c|}
\hline CF:MP & Moisture & Protein & Fat & Ash & Fibre & Carbohydrate \\
\hline Control & $10.11^{\mathrm{c}}$ & $8.02^{b}$ & $3.06^{a b}$ & 2.03 & $2.23^{d}$ & $74.55^{d}$ \\
\hline $95: 5$ & $11.34^{a}$ & $8.84^{a}$ & $3.26^{\mathrm{a}}$ & $2.33^{b}$ & $2.55^{\mathrm{b}}$ & $71.66^{c}$ \\
\hline $90: 10$ & $11.23^{a}$ & $9.36^{a}$ & $3.56^{b}$ & $2.28^{c}$ & $2.46^{a}$ & $71.09^{b}$ \\
\hline $85: 15$ & $10.66^{b}$ & $9.64^{\mathrm{ab}}$ & $3.53^{c}$ & $2.36^{b}$ & $2.73^{c}$ & $71.06^{b}$ \\
\hline $80: 20$ & $11.17^{\mathrm{b}}$ & $9.71^{c}$ & $3.61^{d}$ & $2.56^{a}$ & $2.47 e$ & $70.45^{a}$ \\
\hline $75: 25$ & $11.15^{\mathrm{a}}$ & $10.03^{d}$ & $3.75^{d}$ & $2.43^{\mathrm{bc}}$ & $2.60^{c}$ & $70.03^{a}$ \\
\hline
\end{tabular}

Table 1: Proximate composition of cassava-mushroom bread.

\begin{tabular}{|c|c|c|c|c|}
\hline CF:MP & $\mathrm{Fe}$ & $\mathrm{Ca}$ & K & $\mathbf{P}$ \\
\hline Control & $3.22^{\mathrm{c}}$ & $42.33^{c}$ & $17.23^{a}$ & $5.34^{b}$ \\
\hline $95: 5$ & $5.31^{c}$ & $46.22^{\mathrm{a}}$ & $24.33^{a}$ & $7.22^{d}$ \\
\hline $90: 10$ & $5.32^{a}$ & $46.62^{c}$ & $26.11^{\mathrm{c}}$ & $9.33^{c}$ \\
\hline $85: 15$ & $6.21^{b}$ & $47.21^{a}$ & $30.33^{d}$ & $11.32^{a}$ \\
\hline $80: 20$ & $7.12^{d}$ & $50.31^{a}$ & $35.42^{b}$ & $15.24^{b}$ \\
\hline $75: 25$ & $7.73^{\mathrm{ab}}$ & $53.41^{b}$ & $38.51^{b}$ & $17.53^{\mathrm{ab}}$ \\
\hline
\end{tabular}

Table 2: Mineral composition of cassava-mushroom bread. 


\begin{tabular}{|c|c|c|c|c|c|}
\hline CF:MP & WAC & BD & SWP & OAC & Solubility \\
\hline Control & $93.42^{d}$ & $0.61^{c}$ & $15.35^{c}$ & $9.34^{b}$ & $3.74^{c}$ \\
\hline $95: 5$ & $100.35^{a}$ & $0.69^{c}$ & $11.13^{a}$ & $10.32^{c}$ & $2.23^{a}$ \\
\hline $90: 10$ & $99.95^{b}$ & $0.72^{\mathrm{b}}$ & $11.03^{a}$ & $10.23^{a}$ & $2.17^{b}$ \\
\hline $85: 15$ & $101.23^{a}$ & $0.68^{e}$ & $10.96^{b}$ & $9.92^{c}$ & $2.27^{c}$ \\
\hline $80: 20$ & $99.84^{c}$ & $0.68^{e}$ & $10.92^{b}$ & $9.87^{\mathrm{ab}}$ & $2.14^{d}$ \\
\hline $75: 25$ & $100.23^{a}$ & $0.74^{d}$ & $10.88^{b}$ & $9.67^{a}$ & $2.33^{a}$ \\
\hline
\end{tabular}

Values with the same superscripts in the same column are not significantly $(p>0.05)$ different.

SWP: Swelling power; WAC: Water absorption capacity; OAC: Oil absorption capacity; BD: Bulk density

Table 3: Functional properties of cassava bread with mushroom powder.

\begin{tabular}{|c|c|c|c|c|}
\hline CF:MP & Texture & Flavor & Taste & Appearance \\
\hline Control & $7.11^{\mathrm{a}}$ & $4.22^{\mathrm{a}}$ & $4.62^{\mathrm{a}}$ & $7.64^{\mathrm{d}}$ \\
\hline $95: 5$ & $4.89^{\mathrm{a}}$ & $3.11^{\mathrm{a}}$ & $2.56^{\mathrm{ab}}$ & $4.56^{\mathrm{bc}}$ \\
\hline $90: 10$ & $5.44^{\mathrm{a}}$ & $3.44^{\mathrm{a}}$ & $1.89^{\mathrm{b}}$ & $4.33^{\mathrm{c}}$ \\
\hline $85: 15$ & $6.89^{\mathrm{a}}$ & $4.11^{\mathrm{a}}$ & $4.00^{\mathrm{ab}}$ & $6.44^{\mathrm{ab}}$ \\
\hline $80: 20$ & $6.11^{\mathrm{c}}$ & $4.33^{\mathrm{a}}$ & $4.33^{\mathrm{a}}$ & $6.67^{\mathrm{a}}$ \\
\hline $75: 25$ & $6.00^{\mathrm{a}}$ & $4.36^{\mathrm{a}}$ & $4.11^{\mathrm{ab}}$ & $6.00^{\mathrm{a}}$ \\
\hline
\end{tabular}

Table 4: Sensory properties of cassava bread with mushroom powder.

MP, respectively, while significant difference existed in the rest of the samples. The irregular results obtained are mainly due to the already compacted state of the samples (in baked form) which show little or no difference in the determination of different samples.

The percentage Solubility represents the proportion of the granules which reacts with the solvent completely to form a stable solution. In this study, the highest percentage solubility was recorded in bread samples of 5\% mushroom powder and the lowest was found in samples of $25 \%$ mushroom. The Solubility decreased from $10.32 \%$ to $9.67 \%$. This is caused by the proportion of starch granules which is higher in $5 \%$ mushroom bread than any other samples. Therefore, as the mushroom content decrease, the percentage solubility increased.

\section{Sensory evaluation}

The result of the sensory evaluation of the Cassava-Mushroom composite bread is shown in Table 4 . Bread from sample $85: 15 \%$ of $\mathrm{CF} / \mathrm{MP}$, respectively was more acceptable in terms of texture. There was no significant difference at $(p>0.05)$ between the flavors of the bread samples. As the incorporation level of mushroom powder increased flavor also increased. Significant difference existed in taste and appearance of the bread samples compared with the control, Bread from sample $80: 20 \%$ of $\mathrm{CF} / \mathrm{MP}$, respectively were more acceptable in terms of taste and appearance. General acceptability of the bread samples showed that there were no significant differences at $(\mathrm{p}>0.05)$ among the treatments. Among the samples (cassava/mushroom) bread, highest overall acceptability was recorded for sample $75 \%$ CF: $25 \%$ MP. It could be deduced from the table as the mushroom content increased, the general acceptability increased. All the bread batches produced were accepted well with the control.

\section{Conclusion}

The present study had shown that acceptable and nutritious bread could produce from whole replacement of wheat with cassava and mushroom blends, thus this would lower or eliminate the cost of wheat importation, would create jobs and enhance income to Nigeria households. Moreover, it would curb the problems of malnutrition in developing countries.

\section{References}

1. Dewettinc K, Van-Bockstaele F, Kühne B, Van-DeWalle D, Courtens TM, et al.
(2008) Nutritional value of bread: Influence of processing, food interaction and consumer perception. J Cereal Sci 48: 243-257.

2. Akpapunam MA, Darbe JW (1999) Chemical composition and functional properties of blend of maize Barbara groundnuts flours for cookies production. Plant Food Human Nutri 46: 147-155.

3. Lawrence JH, Moore LM (2005) Cassava, Manihot esculenta Crantz. USDA, Washington DC, USA.

4. Onabolu A (1988) Sweet cassava: A food for all seasons. United Nations Children's Fund, Household Food Security and Nutrition Program, USA.

5. Vlavonou BM (1988) Cassava processing technologies in Africa. IITA, Ibadan, Nigeria, UNICEF House pp: 19-25.

6. Adeniji AA, Ega LA, Akoroda MO, Ugwu BO, Balogun A (2001) Global strategy for cassava development. Department of Agriculture, Federal Ministry of Agriculture and Natural Resources, Nigeria.

7. Petrovsica B, Kulevanova S, Stefov V (2002) Infrared analysis of Macedonian mushroom dietary fibre. Molecul Res Food Nutri 46: 238-239.

8. Mallavadhani UV, Sudharkar AVS, Satyanarayana KVS, Mahapatra A, Li W, et al. (2006) Chemical and analytical screening of some edible mushrooms. Food Chem 95: 58-64.

9. Friedman MI (1975) Protein nutritional quality of foods and feeds. Marcel Dekker Inc, NY pp: 308-318.

10. Quimio TH, Changs T, Royse DT (1990) Technical guidelines for mushroom growing in the tropics. FAO, Italy.

11. Srivastava RP, Kumar S (2002) Fruits and vegetable preservation. International book distributing company, Lucknow, India.

12. Okeke JNC, Ozumba AU, Olatunji OO, Odunfa SA (2003) Effect of drying methods on some qualities of Nigerian Pleurotus pulmonarius mushroom powder. Nig Food J 21: 137-143.

13. Kulp-karel, Joseph PG (2000) Handbook of cereal science and technology. Marcel Dekker inc, NY, USA pp: 540-552.

14. AOAC (2000) Official Methods Of Analysis. Association of Official Analytical Chemists, AOAC International, Maryland, USA.

15. Kirk RS, Sawyer R (1991) Pearson's composition and analysis of foods Longman Group Ltd, UK pp: 188- 223.

16. Okaka JC, Potter NN (1977) Functional and storage properties of cowpea powder and wheat flour blend in bread making. J Food Sci 42: 822-833.

17. Sather SK, Salunke DK (1981) Functional properties of great Northern beans (Phoseous rusgaris) protein, emulsion, foaming, viscosity and gelation properties. J Food Sci 46: 71-74. 
Citation: Azeez LA, Adedokun SO, Adeoti AO, Babalola JO (2018) Quality Characteristics of Fortified Bread Produced from Cassava and Mushroom Flours. J Food Process Technol 9: 724. doi: 10.4172/2157-7110.1000724

Page 5 of 5

18. Takashi S, Seib PA (1988) Paste and gel properties of prime corn and wheat starches with and without native lipids. Cereal Chem 65: 474.

19. Iwe MO (2010) Handbook of sensory methods and analysis. Rojoint Communication Services Ltd, Enugu, Nigeria, pp: 75-78.

20. Mahedy M, Rezaul IS, Rabiul H (2012) Fortification of wheat bread using mushroom powder. Bangla Res Publication J 7: 60-68.

21. Okafor JNC, Okafor GI, Ozumba AU, Elemo GN (2012) Quality characteristics of bread made from wheat and Nigerian oyster mushroom powder. Pak J Nutri 11: $5-10$

22. Caglarirmak N (2007) The nutrients of exotic mushrooms (Lentinula edodes and Pleurotus species) and an estimated approach to the volatile compounds. Food Chem 105: 1188-1194.

23. Adebayo EA, Oloke JK, Aina DA, Bora TC (2014) Antioxdant and nutritiona importance of some Pleurotus species. J Micro Biotech Food Sci 3: 289-294.

24. Kulkarni KD, Kulkarni DN, Ingle UM (1991) Sorghum malt-based weaning formulations preparation, functional properties, and nutritive value. Food Nutri Bulletin 13: 322-327.

25. Adebowale AA, Sanni LO, Awonorin SO (2006) Effect of texture modifiers on the physicochemical and sensory properties of dried fufu. Food Sci Tech Int 11: $373-382$ 